\title{
What cognitive psychologists should find interesting about tax
}

\author{
Claire A. Hill \\ University of Minnesota Law School, Minneapolis, Minnesota
}

\begin{abstract}
People have to pay taxes, and usually they do- - even though they would rather not. What determines whether and how much they decide to pay depends on more than a cost-benefit calculation. Results from the literature at the intersection of economics and psychology suggest that many factors are relevant, including people's perceptions of how the money is being spent, and who (else) is being asked to pay taxes. The results also suggest ways in which government may be able to use framing and various biases to influence payment of and attitudes toward tax. But much remains unknown, including, importantly, the extent to which tax incentives influence behavior.
\end{abstract}

For many and, perhaps, most people, tax elicits a visceral and unpleasant reaction - and not just paying tax, but even simply hearing about it, as though it were somehow distasteful. This is true even for law students and many (nontax) lawyers and law professors. As a law professor who sometimes writes about tax I can, and not infrequently do, argue that tax is actually much more interesting than most people think.

Among the interesting questions are those in the realm of psychology: Why do people choose to pay taxes? It is not just because they think they will be caught and punished if they do not. What are the other determinants? If people think others in their community are, or are not, paying tax, does it affect their willingness to pay tax? What about others in their greater society? What principles do people have about how taxes should be assessed? To what extent are people self-serving in their assessments of who should pay what amount of tax? What kinds of strategies can the government use to affect how people feel about tax and their willingness to pay? How do heuristics and biases affect how people perceive particular taxes? Do people's heuristics and biases provide an argument for certain kinds of taxes? All these questions are importantly about the psychology of tax.

\section{TAX COMPLIANCE}

"Where there is an income tax, the just man will pay more and the unjust less on the same amount of income."

$$
\text { - Plato }
$$

"Income tax has made more liars out of the American people than golf."

$$
\text { —Will Rogers, humorist }
$$

"Only the little people pay taxes."

$$
\text { — Leona Helmsley, quoted by her maid }
$$

The issue on which the most work has been done is tax compliance: What determines whether people will choose to pay tax? ${ }^{1}$ The hypothesis that the determination is based purely on a rational cost-benefit analysis - that is, a computation of how likely a person is to get caught if he does not pay, how much tax he can avoid, the legal consequences of being caught, and how much trouble it takes to avoid tax - has been soundly rejected. People comply a great deal more than such considerations can justify: Paying tax is, in significant measure, voluntary, given current levels of enforcement (Andreoni, Erard, \& Feinstein, 1998; Cullis, Jones, \& Lewis, 2006a, 2006b; Feld \& Frey, 2007; Kirchler, 2007; Torgler, 2007). There is evidence for each of the following as a determinant of tax compliance: a person's ethics, religious beliefs, moral conscience, and honesty; whether a person anticipates guilt and shame from noncompliance; ${ }^{2}$ and the social norms of the group a person identifies with (Kirchler, 2007; Torgler, 2007). A generic recourse to risk aversion might work as an explanation - people will pay a great deal to avoid risk, even if the risk is remote-but such an explanation is distinctly unsatisfying, especially given the size of the benefit relative to any plausible estimation of the risk. ${ }^{3}$

Of course, economic factors are relevant-most notably, the probability of detection. All else being equal, a person who receives some income in cash "off the books" is less likely to report it than is someone who receives a paycheck in the same amount for the same work, where the salary information is also being sent by the employer to the IRS. But the other factors mentioned, particularly psychological and "moral" factors, are clearly very important determinants of tax compliance.

C. A. Hill, hillx445@umn.edu 


\section{Societal Factors}

Societal factors relevant to whether people will choose to pay their taxes include such things as perceptions of whether the tax system is fair, how well the government will spend the money, who the government will spend the money on, whether the system is procedurally fair, and whether people who do not comply are being punished (Kirchler, 2007; Torgler, 2007). It may matter, for instance, whether tax law's complexity makes ordinary taxpayers think that those with money can pay less by paying to find loopholes. If a person thinks others in the society are paying taxes, he or she may be more apt to pay his or her own taxes. It may matter whether a person thinks he or she is being treated respectfully by the government or whether the government is viewing itself as a superior authoritarian figure in a hierarchy.

How people appraise the level of public services they are getting, whether they think the government is good at providing public services, whether they in general agree with the government's spending priorities and projects, whether and to what extent they think taxes should be progressive (with the highest amounts paid by the richest people), all matter (Feld \& Frey, 2007; Kirchler, 2007; Torgler, 2007). If someone thinks that the government is inefficient at doing much of anything, he or she may very well think that paying as little tax as is consistent with avoiding legal sanction is appropriate. If someone thinks that he or she has benefited greatly from some public project, he or she may be inclined to choose to pay more. In wartime, a time of national emergency, or instillation of a sense of the necessity of shared sacrifice, tax compliance may go up as well; however, one study has suggested that "across countries, interstate military conflicts increase positive attitudes toward tax compliance, but military fatalities undermine it" (Feldman \& Slemrod, 2009).

Which of these factors count, and how much do they count? How do these factors interact? Different research has shown different results. Much of this research squares with intuition ("honest" people-i.e., people who are honest with respect to things other than tax-evade less than do less honest people, including as to off-the-books income; it matters if one thinks that others are evading; it matters if one has more of an identification with the community to which one is paying tax and from which one is enjoying public goods); some does not (some studies have shown that perceived fairness of the system does not matter; Porcano, 1988). One study examined what happened when the state of Minnesota, investigating compliance methods, randomly selected a set of taxpayers to get letters saying that their returns would be "closely examined." It showed that whereas low- and middle-income taxpayers, especially those with greater opportunities to evade taxes, increased their reported income and hence their tax liability, high-income taxpayers reported lower tax liability (Slemrod, Blumenthal, \& Christian, 2001). The authors considered the possibility that such taxpayers "tend to believe that the outcome of the audit process is more manipulable, and the final outcome is more dependent on their report, than other taxpayers" (Slemrod et al., 2001, p. 480).
Feld and Frey (2007) hypothesized an implicit "psychological tax contract" between taxpayers and the government, a "complicated interaction between taxpayers and the government establishing a fair, reciprocal exchange that involves giving and taking of both parties" (p. 104). Even if citizens are not receiving equal value in public services for their tax payments, they may nevertheless be willing to honestly declare their income and pay tax if they think that the process by which the tax was assessed is fair, the state's policy outcomes are legitimate, and the system treats its citizens respectfully. "The psychological tax contract has elements of gain (or distributional justice) and participation (or procedural justice) ... [and] also elements of respect (or interactional justice)" (Feld \& Frey, 2007, p. 104). Part of the authors' policy prescription involves a recognition that enforcement (here, by tax authorities) can sometimes crowd out internalized incentives, an effect well recognized in several fields. The point warrants emphasis. When government is trying to maximize tax compliance, the obvious methods by which it generally tries to influence behavior-increasing punishment and probabilities of detection - may be counterproductive.

\section{Noncompliance}

There are different types of noncompliance. One type of noncompliance is quite rare: for an employee to not report salary payments, because employers report these payments directly to the IRS. The government has been told of the income and, therefore, has an easy way of checking whether taxes have been paid on it. But apart from this, there is a great deal of noncompliance. Some people do not report or underreport other income they receive. Some people claim deductions from their income that may constitute an aggressive interpretation of the rules or may even be altogether fictitious, such as personal expenses labeled as business expenses or "expenses" not incurred at all. Some people spend time and effort (and often money) looking for legal ways (colloquially sometimes called loopholes) to reduce their taxes; this behavior is technically not noncompliance, but it would be regarded by many as being at least less than fully compliant (Hickman \& Hill, 2010). Aggressive interpretations of tax rules are often called avoidance; lying and concealing income, and other like acts, are often called evasion (Kirchler, 2007). There may be differences in the psychology of evasion and of avoidance; there are also differences as to one's views of what one should do and one's judgments as to others' behavior. A person may find his or her own use of a particular tax strategy acceptable while condemning something comparable in others.

Of course, the key questions are which of these factors count, and how should the tax system be structured, given the answers? Research is continuing on these very difficult questions.

\section{(NEGATIVE) VIEWS OF THE TAX SYSTEM}

"The only difference between a tax man and a taxidermist is that the taxidermist leaves the skin."

- Mark Twain 
"People who complain about taxes can be divided into two classes: men and women."

$$
\text { - Unknown }
$$

"Be wary of strong drink. It can make you shoot at tax collectors ... and miss."

\section{— Robert A. Heinlein}

All else being equal, a negative view of the tax system should lead to less compliance. Do people have such a view? It is almost a commonplace that they do. A negative view of the tax system goes beyond, of course, a simple dislike of having less money because one has given some to the government. Among the common negative views are that the tax system is unduly complicated and unfairly skewed toward rich people, who can afford expensive tax advice to help them "beat the system" (Cunningham \& Repetti, 2004). But this does not mean that "rich people" have more favorable views of the tax system; quite the contrary. Those with higher incomes may feel particularly negatively and think avoidance and even evasion of taxes is acceptable (Kirchler, 2007). Moreover, some surveys have shown that people think tax evaders are quite intelligent and hard working (Kirchler, 2007, p. 52), suggesting they do not hold it against the tax evaders that they are evading tax and, instead, are lauding their skill at doing so.

All this being said, not everyone has a negative view of the tax system. Some people think well of the government and want to contribute to public goods; some wealthy people, like Warren Buffett, think that it is their duty to do so. When a permanent repeal of the estate tax was being debated, Buffett said that

dynastic wealth, the enemy of a meritocracy, is on the rise. Equality of opportunity has been on the decline .... A progressive and meaningful estate tax is needed to curb the movement of a democracy toward plutocracy. (Drawbaugh, 2007)

Buffett's view is in stark contrast to that of many others, including people who would not be subject to any estate tax thus far in effect or reasonably debated because they do not have nearly enough money; the estate tax is not popular. One might think that people would be delighted to support a tax to be paid by others; apparently, they are not. Loewenstein, Small, and Strnad (2006) have discussed several possible explanations. One, which they largely dismiss, is that many people think that they will become wealthy and, hence, that their estates will be subject to the estate tax. They argue that "it is hard to imagine that this delusion affects a large enough proportion of the population to create the existing and historical level of discomfort with the estate tax" (p. 40). Another is that those who would be subject to the estate tax "hide behind selected widows." "The specter of individual small business owners or farmers being forced to sell out what their parents built up solely to pay estate taxes created a politically compelling victim scenario entirely separate from the political power of these groups as such" (Lowenstein et al., p. 40, quoting Graetz, 1983, p. 274).

Interestingly, views about tax, both positive and negative, may be embedded in the language, as Kirchler (2007) discussed. Kirchler quoted Schmölders as follows:
Whereas, in the Latin world, the word tax means something felt as an "impostation" upon the citizen (impot, imposto, impuesto), the German word "Steuer" means "support" and the Scandinavian "skat" the common treasure put aside for common purposes. (p. 40)

It seems likely that language reflects, and may also reinforce, ways in which people in a particular linguistic community think of tax; its role may be even more profound, if, as some researchers have recently resuggested, language importantly influences thought (e.g., Boroditsky, 2001).

\section{BEHAVIORAL PUBLIC FINANCE}

In recent years, the findings from psychology that people's decisions deviate from the classical rationality assumptions of economics have made their way into law under the label of behavioral law and economics. With regard to taxes (and other areas of public funding), the label is behavioral public finance (McCaffery \& Slemrod, 2006a). In this section, I consider not only how these findings are relevant to people's perceptions, attitudes, and behavior, but also how they are relevant to the behavior of the government.

\section{Framing Effects}

The previous section discussed compliance as a function of taxpayer perceptions of things such as the size of the tax burden and fairness in its implementation. But how do people come to those perceptions? And how does government act to affect those perceptions?

Framing effects are rife in tax. Examples include the following:

Subjects react differently depending on the unit in which a question is posed, preferring, for example, a tax system featuring higher taxes when asked about taxes in percent rather than in dollar terms. Other examples include ... tax aversion, wherein people prefer government surcharges described as something other than a tax, such as a payment or user fee. (McCaffery \& Slemrod, 2006b, p. 7)

The authors also note that "many smaller taxes can add up to a greater total tax burden, with the same psychic discomfort, as fewer larger taxes, because people do not sum them up fully in their minds" (McCaffery \& Slemrod, 2006b, p. 9).

It has been argued that the government can and does use framing effects to minimize taxpayers' perceived tax burden (Krishna \& Slemrod, 2003). The same tax can be framed as a discount from a high base or a penalty from a low base; the framing apparently matters. The authors gave the following example:

Schelling (1981) pointed out that the tax table can be constructed by using as a default case either a childless family (as is currently done) or, for example, a two-child family. The tax difference between a childless family and a two-child family is naturally framed as an exemption (for the two-child family) in the first 
frame and as a tax premium (for the childless family) in the second frame. Schelling reported that this seemingly innocuous difference had a large effect on student judgments of the preferred relationship between income, family size, and tax liability. The students rejected the idea of granting the rich a larger exemption than the poor in the first frame, but favored a larger tax premium on the childless rich than on the childless poor in the second frame. (Krishna \& Slemrod, 2003, p. 191)

Krishna and Slemrod (2003) made other, similar arguments regarding, among other things, how tax cuts might be presented in political campaigns - how much better off would someone feel getting a tax cut that would enable her to buy one candy bar a day? - and the government's desire to "hide" sales taxes as conflicting with a merchant's desire to depict its prices as lower by presenting the sales tax separately.

Framing may also affect how tax rates are selected. Prices that end with a 9 are perceived by consumers to be lower than prices one cent higher. Although the United States tax system has many 9 endings, the authors note that

9 endings have not always prevailed for the top tax rate in the US. From 1964 to 1981 the top tax rate was $70 \%$, and from 1981 to 1986 it was 50\%. Among all developed countries, the top individual marginal tax rates seem to cluster at low endings rather than high endings. ... This bunching at low endings suggests that these tax systems are designed to maximize the burden of the richest taxpayers perceived by the typical voter, and thereby to minimize the perceived burden of the typical voter. (Krishna \& Slemrod, 2003, p. 197; cf. Baron \& McCaffery, 2006, pp. 110-111)

The foregoing implies that perceptions are quite contingent. An important question is whether government, or anyone else, can systematically figure out how to shape them. Can government get more people to pay more taxes, or make more people happy with the tax system, by artful use of framing?

\section{Heuristics and Biases: Availability}

The government seems to know how to use the availability heuristic to make people comply with or approve of tax. As a notable example, the government takes advantage, whether or not intentionally, of the availability heuristic when it arranges for high-profile tax prosecutions on April 15 (Podgor, 2009). Availability was also at issue when the government abandoned its program of audits under the Taxpayer Compliance Measurement Program:

It appears that the program met its demise largely because "victim" concerns became salient. The experiences of various audited individuals became public, exposing the comprehensive (and painful) nature of the audit and emphasizing that it fell at random. As a result, the audit picked up the descriptor "audit from hell" and was an early and prominent casualty of the taxpayer rights movement. The IRS halted the program in 1995. . . Part of the problem seems to have been a strong reluctance on the part of the IRS to compensate the "victims" of the audits with monetary payments or otherwise in the face of a public belief that those audited richly deserved such compensation. (Loewenstein et al., 2006, p. 41)

The same article also gives a history of the passage of the alternative minimum tax (AMT), a tax that kicks in to make people with high incomes who would otherwise pay "too little" tax on account of their many deductions pay some tax. It notes that although serious proposals for an AMT-type tax had been considered for a long time, the tax was passed only after the temporary Secretary of the Treasury at the end of the Johnson administration announced that "154 taxpayers had adjusted gross incomes of $\$ 200,000$ or more (approximately $\$ 800,000$ in 2004 dollars) but taxable incomes of zero. This announcement generated more letters to Congress during 1969 than the Vietnam War" (Loewenstein et al., 2006, p. 43).

\section{Heuristics and Biases: Discounting and Optimism Biases}

One way of using taxes to change behavior was discussed by Fang and Silverman (2006). Given that people generally have an optimism bias, which for this purpose means that they overestimate the likelihood that they can quit smoking or not get a smoking-caused disease and may also be biased toward immediate gratification, very high cigarette taxes might be seen as ways to counter those biases. They noted that "present-biased preferences may harm smokers by causing them to oversmoke with respect to their own normative or long-term preferences if they were to see their world without bias and make decisions from a temporal distance" (Fang \& Silverman, 2006, p. 51).

\section{VIEWS ABOUT WHO SHOULD PAY TAXES}

The 400 of us [at a $\$ 4,600$-a-seat fundraiser in New York for Senator Hillary Clinton] pay a lower part of our income in taxes than our receptionists do, or our cleaning ladies, for that matter. If you're in the luckiest 1 per cent of humanity, you owe it to the rest of humanity to think about the other 99 per cent.

\section{— Warren Buffett}

There isn't much consensus about who "should" pay taxes. Differences are possible on many different dimensions. A person might think that particular activities should be rewarded in the form of tax reduction - people should be rewarded for giving to charity, for instance. A person might think that the measure of "income" or "accretions" to wealth reduces incentives to work or rewards people who do not work. A person might think that ability to pay is relevant; another might not.

\section{Do People Have Principled Positions About Tax?}

A tax loophole is something that benefits the other guy. If it benefits you, it is tax reform.

— Russell B. Long, U.S. Senator 
For many people, the answer to the question above seems to be no. Contrast the following two scenarios. An individual who works in State A chooses to live in nearby State B because State B has a lower income tax. A company that does most of its business in Country A chooses to "live" (incorporate) in Country B because Country B has lower tax rates. Intuition suggests that laypeople would find the individual's actions acceptable; for the company, there is considerable outcry when the company's choice becomes known ("US firm," 2002). Some might argue that one rule for "the little guy" and another for big business is a bad principle; although some may hold this to be a bad principle, many people more likely reflexively resist higher tax liability themselves but, acknowledging the need for the government to raise money, take the position that someone different from them (e.g., a corporation) should be liable. The phenomenon is familiar from many other contexts: Consider NIMBY, or "not in my back yard," the reflexive objection to placement of some undesirable thing (a halfway house or a garbage dump, for instance) in one's neighborhood.

Relatedly, there may be such a thing as folk tax intuitions - intuitions that many people have about tax that are sometimes held self-righteously and that are counter to existing tax law. If Neighbor A gives Neighbor B cookies in exchange for Neighbor B's watching Neighbor A's cat while Neighbor A is away, both owe income tax for the services they provided for which they were paid. But this conclusion would be resisted by many, and perhaps most, people. Barter does not seem like "income" somehow. And here, the action was after hours and between friends and neighbors. People may think that exchanged favors between people whose relationship is social rather than professional do not come within a frame that would warrant compensation in the form traditional for business (Heyman \& Ariely, 2004). Perhaps, though, A is a professional baker, and $\mathrm{B}$ is a professional cat sitter. That would seem to support an intuition that the transaction was taxable. Or take a stronger case: Accountant $C$ renders accounting services to Electronics Technician D in exchange for D's fixing C's flat-screen television. Here, the services look more like things that are "generally taxable." But even in this case, some people have the intuition that the transaction should not be taxable, notwithstanding its equivalence to a clearly taxable transaction in which the accountant got money from $\mathrm{D}$ for doing the accounting work and then paid $\mathrm{D}$ for fixing his television. When people feel something should not be taxable and the government has no ready enforcement mechanism, we might expect compliance to be exceedingly low.

The general principle here seems to be no cash, no tax. The tax system requires tax payments in quite a few contexts where no cash changes hands. Where does the intuition that these transactions should not be taxable come from? Is it at all malleable? If so, how?

\section{Extrapolations From Behavior About Taxes}

I noted above that some evidence suggests that people think that tax evaders are intelligent and hard working (Kirchler, 2007, p. 52). What do people think of a cor- poration's aggressiveness as to its tax liability? Some evidence suggests that the signal sent is negative: The company's stock price goes down in response to an initial press mention that a corporation has been involved in a corporate tax shelter. But not by much - not nearly as much as when an accounting misdeed is revealed (Hanlon \& Slemrod, 2009). There may be a pure economic story; markets may think that the company may become subject to fines or penalties. (And markets apparently do not mind when it is disclosed that a company managed to have a very low effective tax rate; tax aggressiveness that does not seem to be linked to possible fines or penalties seems unobjectionable; Hanlon \& Slemrod, 2009.) But there may be more interesting psychological stories. People may think that if the company is focusing attention on tax schemes, it is neglecting its business. Or they may think that if the company is willing to use tax schemes, it may also be willing to play fast and loose in business generally. Interestingly, tax lawyers sort themselves by reputation. Those willing to be involved in more aggressive tax planning come to be known as such (Hill, 2007).

\section{SOME OTHER IMPORTANT QUESTIONS}

The tax law has two, sometimes contrary objectives. One is to raise money. The other is to influence behavior (Hickman \& Hill, 2010). There are many interesting questions, some much studied, as to how and how much people will change their behavior in response to tax. Will they do what tax attempts to influence them to do? Notable examples are to buy a house, rather than rent, and to make charitable contributions. How much does the tax incentive affect the choice? Do people choose to marry or not, or have children or more children, on the basis of the availability of tax benefits? Another set of questions involves the extent to which increasing the taxes on an activity will discourage people from doing it. The classic question, as to which there is volumnious (ultimately inconclusive) empirical work, is whether people will work less if the marginal income tax rate is increased; indeed, with respect to all of these issues, empirics are extensive but have not resolved the debate. The psychology here is quite interesting. As in the standard psychological research demonstrating that people with prior beliefs in one direction interpret the mass of data to establish their position conclusively, people who believe that higher marginal rate means less work believe that the empirical research supports their position, but this is open to significant question (Frank, 2007).

I hope I have convinced you that the issues of taxof perception, judgment, and behavior - are very much issues of cognitive psychology. There is much more research to be done.

\section{AUTHOR NOTE}

Correspondence concerning this article should be addressed to C. A Hill, Institute for Law and Rationality, University of Minnesota Law School, 229 19th Avenue South, Minneapolis, MN 55455 (e-mail: hillx445@umn.edu). 


\section{REFERENCES}

Andreoni, J., Erard, B., \& Feinstein, J. (1998). Tax compliance. Journal of Economic Literature, 36, 818-860.

BARON, J., \& McCAFFERY, E. J. (2006). Masking redistribution (or its absence). In E. J. McCaffery \& J. Slemrod (Eds.), Behavioral public finance (pp. 85-112). New York: Sage.

Boroditsky, L. (2001). Does language shape thought? Mandarin and English speakers' conceptions of time. Cognitive Psychology, 43, 1-22. doi:10.1006/cogp.2001.0748

Cullis, J., Jones, P., \& Lewis, A. (2006a). Tax evasion: Artful or artless dodging? In E. J. McCaffery \& J. Slemrod (Eds.), Behavioral public finance (pp. 233-258). New York: Sage.

Cullis, J., Jones, P., \& Lewis, A. (2006b). Tax framing, instrumentality and individual differences: Are there two different cultures? Journal of Economic Psychology, 27, 304-320.

Cunningham, N. B., \& Repetti, J. R. (2004). Textualism and tax shelters. Virginia Tax Review, 24, 1-63.

Drawbaugh, K. (2007, November 14). Buffett backs estate tax, decries wealth gap. Retrieved from www.reuters.com/article/ousiv/ idUSN1442383020071114.

FAng, H., \& Silverman, D. (2006). Distinguishing between cognitive biases. In E. J. McCaffery \& J. Slemrod (Eds.), Behavioral public finance (pp. 47-81). New York: Sage.

Feld, L. P., \& Frey, B. S. (2007). Tax compliance as the result of a psychological tax contract: The role of incentives and responsive regulation. Law \& Policy, 29, 102-120.

Feldman, N., \& Slemrod, J. (2009). War and taxation: When does patriotism overcome the free-rider impulse? In I. Martin, A. K. Mehrotra, \& M. Prasad (Eds.), The new fiscal sociology: Taxation in comparative and historical perpective (pp. 138-154). Cambridge: Cambridge University Press.

FrANK, R. (2007, April 12). In the real world of work and wages, trickledown theories don't hold up. The New York Times. Available at www .nytimes.com/2007/04/12/business/12scene.html.

Graetz, M. (1983). To praise the estate tax, not to bury it. Yale Law Journal, 93, 259-286.

Hanlon, M., \& Slemrod, J. (2009). What does tax aggressiveness signal? Evidence from stock price reactions to news about tax aggressiveness. Journal of Public Economics, 93, 126-141.

Heyman, J., \& Ariely, D. (2004). Effort for payment: A tale of two markets. Psychological Science, 15, 787-793.

Hickman, K., \& Hill, C. A. (2010). Concepts, categories and compliance in the regulatory state. Minnesota Law Review, 94, 1151-1201.

Hill, C. A. (2007). Tax lawyers are people too. Virginia Tax Review, 26, 1065-1068
KIRChLER, E. (2007). The economic psychology of tax behaviour. Cambridge: Cambridge University Press.

Krishna, A., \& Slemrod, J. (2003). Behavioral public finance: Tax design as price presentation. International Tax \& Public Finance, 10, 189-203.

Loewenstein, G., Small, D., \& Strnad, J. (2006). Statistical, identifiable and iconic victims. In E. J. McCaffery \& J. Slemrod (Eds.), Behavioral public finance (pp. 32-46). New York: Sage.

McCaffery, E. J., \& Slemrod, J. (Eds.) (2006a). Behavioral public finance. New York: Sage.

McCaffery, E. J., \& Slemrod, J. (2006b). Toward an agenda for behavioral public finance. In E. J. McCaffery \& J. Slemrod (Eds.), Behavioral public finance (pp. 3-31). New York: Sage.

Podgor, E. S. (ED.) (2009, April 15). April 15th-Tax day is approaching. Retrieved from http://lawprofessors.typepad.com/ whitecollarcrime_blog/2009/04/april-15th-tax-day-is-approaching .html.

Porcano, T. M. (1988). Correlates of tax evasion. Journal of Economic Psychology, 9, 47-67.

Schmölders, G. (1960). Das Irrationale in der öffentlichen Finanzwirtschaft. Frankfurt am Main: Shurkamp. Quoted in E. Kirchler (2007), The economic psychology of tax behaviour. Cambridge: Cambridge University Press.

Slemrod, J., Blumenthal, M., \& Christian, C. (2001). Taxpayer response to an increased probability of audit: Evidence from a controlled experiment in Minnesota. Journal of Public Economics, 79, 455-483.

Torgler, B. (2007). Tax compliance and tax morale: A theoretical and empirical analysis. Cheltenham, U.K.: Elgar.

US FIRM DITCHES TAX DODGE (2002, August 2). BBC News, World Edition. Available at http://news.bbc.co.uk/2/hi/business/2167602.stm.

\section{NOTES}

1. The tax at issue is generally a tax on income and earnings. There is some work, as well, on other types of taxes - an example being VAT, a type of sales tax.

2. A person's intrinsic motivation to pay tax is sometimes referred to as tax morale or tax ethics (Feld \& Frey, 2007; Torgler, 2007).

3. One might consider risk preferences a psychological factor, but economists very often use the concept; hence, I have categorized it as within the economic account of tax compliance.

(Manuscript received June 25, 2009; revision accepted for publication October 11, 2009.) 